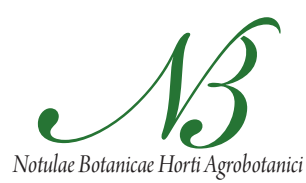

Cluj-Napoca

\title{
Comparison of Some Physico-Mechanical Nut and Kernel Properties of Two Walnut (Juglans regia L.) Cultivars
}

\author{
Sezai ERCISLI'**, Mazhar KARA², Ismail OZTURK², Bahadir SAYINCI ${ }^{2}$, Fatih KALKAN² \\ ${ }^{1}$ Ataturk University Agricultural Faculty Department of Horticulture 25240 Erzurum, Turkey; sercisli@gmail.com ("corresponding author) \\ ${ }^{2}$ Ataturk University Agricultural Faculty Department of Agricultural Machinery 25240 Erzurum, Turkey
}

\begin{abstract}
Some physical such as length, width, thickness, mass, geometric mean diameter, sphericity and surface area and mechanical properties such as deformation at cracking, cracking force, energy absorbed and hardness of nuts and kernels were determined at three orientations first time for two walnut cultivars, namely 'Maraş-18' and 'Yalova-1' widely grown in Turkey. For nuts, the average length (45.48 mm), mass $(12.70 \mathrm{~g})$, geometric mean diameter $(36.83 \mathrm{~mm})$ and surface area $\left(42.66 \mathrm{~cm}^{2}\right)$ were the highest in cv. 'Yalova-1' while width (34.18 $\mathrm{mm})$, thickness $(33.74 \mathrm{~mm})$, shell thickness $(1.48 \mathrm{~mm})$ and sphericity $(87.41 \%)$ were the highest in cv. 'Maraş-18'. For all the loading orientations, the values of deformation at cracking, cracking force, energy absorbed and hardness of cv. 'Maraş- 18 ' were higher than those of cv. 'Yalova-1'. The effect of loading orientation to kernel extraction quality was found insignificant for both walnut cultivars.
\end{abstract}

Keywords: kernel, nut, physical and mechanical characteristics, walnut

\section{Introduction}

Turkey is one of the most important countries in the world in terms of walnut production. The country produces annually 171.000 tons walnut and ranking $3^{\text {rd }}$ place after China (829.000 tons) and USA (396.000 tons) (FAO, 2008). Anatolia is also germplasm center of walnut and walnut trees exceptionally are abundant almost all regions in Turkey. Walnut trees are cultivated in Turkey mainly for its nutritious nuts which used as a food, in the chocolate industry, for baked foods, and in the pharmaceutical and cosmetic industry. The trees are also valuable as timber (Baytop, 1984; Ercisli, 2004). Continuous seed propagation for thousands of years in Turkey has given rise to a great number of seedling walnut trees, which represent valuable walnut gene resources. The number of native trees is estimated to be over 5 million and they possess large genetic variability in yield, nut and kernel characteristics, late bud breaking, late flowering, winter hardiness, tolerance to disease etc. (Ercisli, 2004; Sen and Tekintas, 1992). More recently importance of propagation by grafting and budding is being realized among growers and as a result the orchards established by standard cultivars are becoming increasingly widespread. These standard walnut orchards are generally planted with cultivars mostly selected in Turkey (Barut, 1997). Two of the most common cultivars are 'Yalova-1' and 'Maras-18'. 'Yalova-1' has protandry, however 'Maras-18' has protogyny flower biology characteristics (Anonymous, 2009).

Previously some studies were conducted to determine physical and mechanical properties of several nuts such as cashew (Balasubramanian, 2001; Oloso and Clarke, 1993), neem (Visvanathan et al., 1996), macadamia (Bra- ga et al., 1999), almond (Altuntas et al., 2010; Arslan and Vursavus, 2008; Aydin, 2002; Pliestic et al., 2008;), pistachio (Galedar et al., 2009; Kashaninejad et al., 2006) and walnut (Altuntas and Ozkan, 2008; Caglarirmak, 2003; Kocturk and Gurhan, 2007; Koyuncu et al., 2004).

However in the literature there was no study comparing physical and mechanical properties of two walnut cultivars, 'Yalova-1' and 'Maraş-18', in Turkey. Therefore the aim of this study to determine some important physical and mechanical properties of these cultivars and then establish convenient reference tables for walnut mechanization and processing.

These properties are major dimensions, geometric mean diameter, mass, sphericity, and surface area of both nuts and kernels; cracking force, deformation at cracking, energy absorbed, and hardness of nuts at three orientations and shell thickness, and kernel extraction quality.

\section{Materials and methods}

In this research, two common walnut cultivars, 'Yalova-1' and 'Maraş-18' were used in the experiments. The cultivars were supplied from local producers in Düzce ('Yalova-1') and Kahramanmaraş ('Maraş-18'). All tests were carried out at the Biological Material Laboratory in Agricultural Machinery Department of Ataturk University, Erzurum, Turkey.

The moisture content of shells and kernels were determined by the standard oven drying method at $105^{\circ} \mathrm{C}$ for $24 \mathrm{~h}$ (Koyuncu et al., 2004).

Moisture content values of cvs. 'Maraş-18' and 'Yalova-1' were found to be $8.58 \%$ and $13.51 \%$ for shell and 
228

$3.26 \%$ and $5.58 \%$ for kernel, respectively. Kernel extraction quality was determined by classifying into grades defined in Tab. 1 according to Koyuncu et al. (2004). The test was repeated twenty times.

Axial dimensions of walnut and kernel as length $(L)$, width $(W)$ and thickness $(T)$ were measured by using a digital caliper gauge with a sensitivity of $0.01 \mathrm{~mm}$. Nut and kernel masses were measured by using a digital balance with a sensitivity of $0.01 \mathrm{~g}$ using twenty nuts and kernels.

Geometric mean diameter $\left(D_{g}\right)$, and sphericity $(\phi)$ were calculated by using the following equations (Mohsenin, 1986):

$$
\begin{gathered}
D_{g}=(L W T)^{1 / 3} \\
\varphi=\frac{D_{g}}{L} 100
\end{gathered}
$$

where $D$ is the geometric mean diameter in mm, $\Phi$ is the spherecity in $\%$.

The surface area $(S)$ of the fruit was calculated from the relationship given by Baryeh (2001):

$$
S=\pi D_{g}^{2}
$$

where $S$ is the surface area in $\mathrm{mm}^{2}$.

The mechanical properties for three compression orientation, length, width and suture (Fig. 1) of the nuts were determined by a quasi-static loading device (Turgut $e t$ al., 1998). The device consists of three main units: A load cell connected to a stationary upper plate, a lower plate mounted to a driving unit and a PC equipped with a data acquisition system (DAS). A single nut was placed on the lower plate and the plate moved up with a fixed speed of 0.027 $\mathrm{mm} \mathrm{s}^{-1}$ compressing the nut between two parallel plates until it cracked. The load cell sensed the force applied to the sample which increased with time and transmitted the data to the DAS. The test was repeated twenty times.

Deformation of each nut occurred during the loading up to the crack was determined from the fixed loading speed and time (Altuntas and Yildiz, 2007). Cracking force was directly measured. Energy absorbed during the loading up to crack was calculated from the area under the load-deformation curve using the following equation (Altuntas and Yildiz, 2007; Mohsenin, 1986):

$$
E_{a}=1 / 2\left(F_{r} D_{r}\right)
$$

where $E$ is the energy absorbed in $\mathrm{mJ} ; F_{r}$ is the cracking force $(\mathrm{N})^{2} ; D_{r}$ is the deformation at cracking in $\mathrm{mm}$.

Hardness $(Q)$ was calculated by dividing the cracking force by the deformation at cracking (Sirisomboon et al., 2007):

$$
Q=F_{r} / D_{r}
$$

where $Q$ is the hardness in $\mathrm{N} \mathrm{mm}^{-1}$.
Tab. 1. Evaluation of kernel extraction quality

\begin{tabular}{cc}
\hline Number of parts of kernel extracted & Grade \\
\hline 2 & 100 \\
3 & 80 \\
4 & 60 \\
5 & 40 \\
6 & 20 \\
7 & 10 \\
\hline
\end{tabular}

${ }^{*}$ Whole body has two main parts.

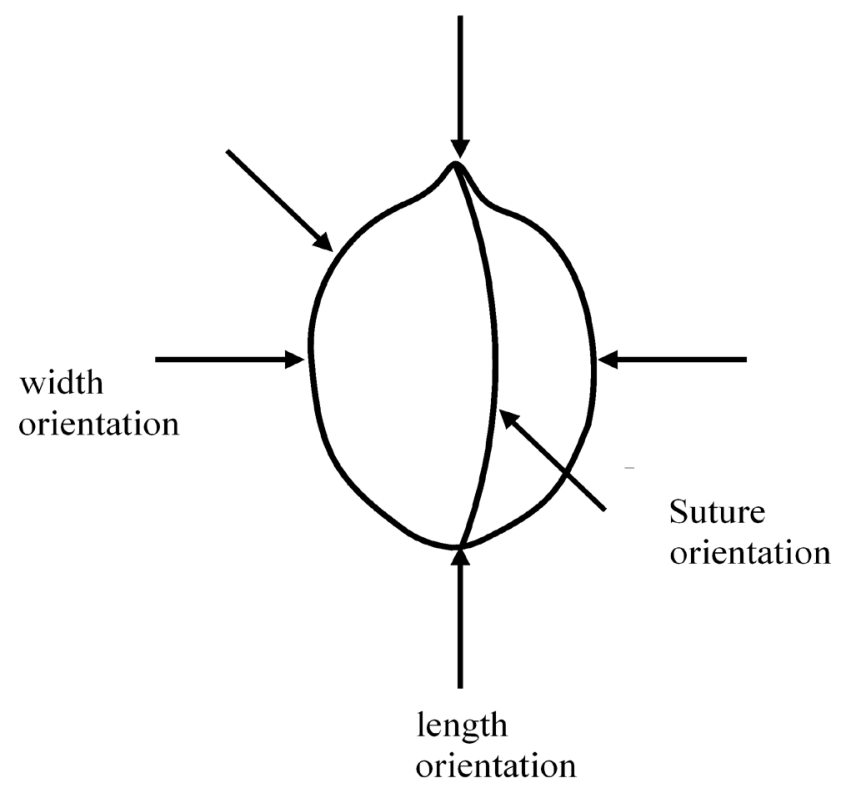

Fig.1. Representation of the three axes for the walnut compression test

\section{Results and discussion}

\section{Physical properties}

The physical properties of nuts and kernels of cultivars as length, width, thickness, nut mass, shell thickness, geometric mean diameter, sphericity and surface area are given in Tab. 2.

In case of nuts and kernels, it has been found significant differences $(P<0.01)$ between cultivars on all searched parameters except width, mass, geometric mean diameter and surface area for nuts and mass for kernels (Tab. 2).

For nuts, the average length, width, thickness, mass, shell thickness, geometric mean diameter, sphericity and surface area were found about $41.57 \pm 1.74 \mathrm{~mm}, 34.18 \pm$ $1.25 \mathrm{~mm}, 33.74 \pm 1.22 \mathrm{~mm}, 12.44 \pm 1.18 \mathrm{~g}, 1.48 \pm 0.13$ $\mathrm{mm}, 36.33 \pm 1.27 \mathrm{~mm}, 87.41 \pm 1.68 \%$, and $41.48 \pm 2.87$ $\mathrm{cm}^{2}$ for $\mathrm{cv}$. 'Maraş-18'. The corresponding values were $45.48 \pm 2.47 \mathrm{~mm}, 34.06 \pm 1.25 \mathrm{~mm}, 32.29 \pm 1.45 \mathrm{~mm}$, $12.70 \pm 1.84 \mathrm{~g}, 1.24 \pm 0.14 \mathrm{~mm}, 36.83 \pm 1.44 \mathrm{~mm}, 81.08 \pm$ $2.41 \%$, and $42.66 \pm 3.38 \mathrm{~cm}^{2}$ for cv. 'Yalova- 1 '. The values of thickness, shell thickness and sphericity of cv. 'Maraş18 ' were higher than those of cv. 'Yalova-1', except for the length. 
Tab. 2. Physical properties of cvs. 'Maraş-18' and 'Yalova-1'

\begin{tabular}{|c|c|c|c|c|c|}
\hline \multicolumn{6}{|c|}{ Nut } \\
\hline Physical properties & 'Maraş-18' & & 'Yalova-1' & & p level $^{[4]}$ \\
\hline Length, $\mathrm{mm}$ & $41.57 \pm 1.74^{[1]}(38.40-44.72)^{[2]}$ & $\mathrm{b}^{[3]}$ & $45.48 \pm 2.47(42.48-51.15)$ & a & $* *$ \\
\hline Width, mm & $34.18 \pm 1.25(31.29-36.03)$ & $\mathrm{a}$ & $34.06 \pm 1.25(31.53-36.40)$ & a & ns \\
\hline Thickness, mm & $33.74 \pm 1.22(31.36-36.03)$ & a & $32.29 \pm 1.45(29.44-35.00)$ & b & ** \\
\hline Mass, $\mathrm{g}$ & $12.44 \pm 1.18(10.07-14.82)$ & a & $12.70 \pm 1.84(9.83-16.40)$ & a & ns \\
\hline Shell thickness, mm & $1.48 \pm 0.13(1.10-1.86)$ & a & $1.24 \pm 0.14(0.83-1.62)$ & b & $* *$ \\
\hline Geo. mean diameter, $\mathrm{mm}$ & $36.33 \pm 1.27(33.79-37.97)$ & a & $36.83 \pm 1.44(34.53-39.84)$ & a & ns \\
\hline Sphericity,\% & $87.41 \pm 1.68(84.33-90.96)$ & a & $81.08 \pm 2.41(77.41-85.32)$ & b & ** \\
\hline Surface area, $\mathrm{cm}^{2}$ & $41.48 \pm 2.87(35.86-45.29)$ & $\mathrm{a}$ & $42.66 \pm 3.38(37.45-49.86)$ & $\mathrm{a}$ & ns \\
\hline \multicolumn{6}{|c|}{ Kernel } \\
\hline Physical properties & 'Maraş-18' & & 'Yalova-1' & & $\mathrm{p}$ level \\
\hline Length, mm & $32.98 \pm 1.41(30.87-36.38)$ & b & $35.58 \pm 1.91(31.70-40.00)$ & a & ** \\
\hline Width, mm & $28.37 \pm 1.33(25.85-30.03)$ & a & $27.42 \pm 1.45(23.76-29.91)$ & b & * \\
\hline Thickness, mm & $23.45 \pm 1.48(20.65-25.58)$ & b & $24.69 \pm 1.44(20.96-27.09)$ & a & ${ }^{* *}$ \\
\hline Mass, g & $7.38 \pm 0.86(5.67-8.75)$ & a & $7.40 \pm 1.21(4.60-9.37)$ & a & ns \\
\hline Geo. mean diameter, $\mathrm{mm}$ & $27.98 \pm 1.25(25.60-29.65)$ & b & $28.86 \pm 1.22(26.05-30.50)$ & a & * \\
\hline Sphericity,\% & $84.86 \pm 2.01(80.16-87.48)$ & a & $81.21 \pm 2.97(75.81-86.41)$ & b & ** \\
\hline Surface area, $\mathrm{cm}^{2}$ & $24.64 \pm 2.16(20.59-27.62)$ & $\mathrm{b}$ & $26.19 \pm 2.19(21.32-29.22)$ & $\mathrm{a}$ & * \\
\hline
\end{tabular}

${ }^{[1]}$ : mean \pm standard deviation; ${ }^{[2]}$ : minimum-maximum values; ${ }^{[3]}$ :letters indicate the statistical difference within same rows; ${ }^{[4]}$ :Significant levels at $5 \%$ and $1 \%$,

ns: not signifaicant

Considering kernels of both cultivars, the average length, width, thickness, mass, geometric mean diameter, sphericity and surface area were found about 32.98 $\pm 1.41 \mathrm{~mm}, 28.37 \pm 1.33 \mathrm{~mm}, 23.45 \pm 1.48 \mathrm{~mm}, 7.38$ $\pm 0.86 \mathrm{~g}, 27.98 \pm 1.25 \mathrm{~mm}, 84.86 \pm 2.01 \%$ and $24.64 \pm$ $2.16 \mathrm{~cm}^{2}$ for cv. 'Maraş-18'. These values were $35.58 \pm 1.91$ $\mathrm{mm}, 27.42 \pm 1.45 \mathrm{~mm}, 24.69 \pm 1.44 \mathrm{~mm}, 7.40 \pm 1.21 \mathrm{~g}$, $28.86 \pm 1.22 \mathrm{~mm}, 81.21 \pm 2.97 \%$ and $26.19 \pm 2.19 \mathrm{~cm}^{2}$ in cv. 'Yalova-1', respectively. The values of length, thickness, geometric mean diameter and surface area of cv. 'Yalova-1' were higher than those of cv. 'Maraş-18', while the value of width and sphericity were lower. In addition, both cultivars had similar values of mass.

Caglarirmak (2003) found the values of shell thickness for some walnut cultivars, 'Şebin Type-I', 'Körcegöz', 'Karabodur', 'Tozanli' and 'Güvenli' between 1.09 and
$1.24 \mathrm{~mm}$. Also the values of shell thickness determined by Koyuncu et al. (2004) for cv. 'Yalova-3' and 'Altuntas' and Ozkan (2008) for cvs. 'Bilecik', 'Kaman', 'Şebin' were $1.4 \mathrm{~mm}$ and $1.38,1.67,0.99 \mathrm{~mm}$, respectively. These findings are close to the results of the present study. Geometric mean diameter and sphericity values of cvs. 'Bilecik', 'Kaman', 'Şebin' were found to be 34.11, 38.20, $31.89 \mathrm{~mm}$ and $88.48,85.58,87.28 \%$ for nut, respectively and 27.18 , $26.68,25.42 \mathrm{~mm}$ and $82.50,79.51,87.15 \%$ for kernel. The present geometric mean diameter and sphericity values were within limits of those studies.

\section{Mechanical properties}

The average values of deformation at cracking of walnut cultivars are presented in Tab. 3. Compared to the loading orientations, the value of highest deformation at

Tab. 3. Mechanical properties of cvs. 'Maraş-18' and 'Yalova-1'

\begin{tabular}{|c|c|c|c|c|c|c|c|}
\hline \multirow{2}{*}{ Mechanical properties } & \multirow{2}{*}{ Cultivar } & \multicolumn{6}{|c|}{ Loading orientation } \\
\hline & & \multicolumn{2}{|c|}{ Width } & \multicolumn{2}{|c|}{ Length } & \multicolumn{2}{|c|}{ Suture } \\
\hline \multirow{2}{*}{ Deformation at cracking, mm } & 'Maraş-18' & 1.521 & $\mathrm{aA}^{[1]}$ & 1.266 & $\mathrm{aA}$ & 0.740 & $\mathrm{aB}$ \\
\hline & 'Yalova-1' & 1.398 & $\mathrm{aA}$ & 0.850 & $\mathrm{bB}$ & 0.713 & $\mathrm{aB}$ \\
\hline \multirow{2}{*}{ Cracking force, $\mathrm{N}$} & 'Maraş-18' & 227.6 & $\mathrm{aA}$ & 184.8 & $\mathrm{aAB}$ & 150.5 & $\mathrm{aB}$ \\
\hline & 'Yalova-1' & 184.9 & $\mathrm{aA}$ & 117.3 & bB & 131.8 & $\mathrm{aB}$ \\
\hline \multirow{2}{*}{ Energy absorbed, mJ } & 'Maraş-18' & 185.5 & $\mathrm{aA}$ & 132.9 & $\mathrm{aAB}$ & 64.8 & $\mathrm{aB}$ \\
\hline & 'Yalova-1' & 132.2 & bA & 53.3 & $\mathrm{bB}$ & 54.6 & $\mathrm{aB}$ \\
\hline \multirow{2}{*}{ Hardness, $\mathrm{N} \mathrm{mm}^{-1}$} & 'Maraş-18' & 151.3 & $\mathrm{aB}$ & 144.8 & $\mathrm{aB}$ & 208.1 & $\mathrm{aA}$ \\
\hline & 'Yalova-1' & 133.6 & $\mathrm{aB}$ & 140.5 & $\mathrm{aB}$ & 184.7 & $\mathrm{aA}$ \\
\hline \multirow{2}{*}{ Kernel extraction quality } & 'Maraş-18' & 99 & $\mathrm{aA}$ & 95 & $\mathrm{aA}$ & 95 & $\mathrm{aA}$ \\
\hline & 'Yalova-1' & 97 & $\mathrm{aA}$ & 97 & $\mathrm{aA}$ & 96 & $\mathrm{aA}$ \\
\hline
\end{tabular}

[1]: Values in the same column with different lower-case letters (a-b) are significantly different at $\mathrm{p}<0.01$. Values in the same column with different upper-case $(\mathrm{A}-\mathrm{C})$ letters are significantly different at $\mathrm{p}<0.01$. 
230

cracking was determined at width orientation for both of cultivars. For cv. 'Maraș-18' the value of deformation at cracking obtained with width orientation $(1.52 \mathrm{~mm})$ had the highest value, followed by length $(1.27 \mathrm{~mm})$ and suture $(0.74 \mathrm{~mm})$ orientation. The values of deformation at cracking of cv. 'Yalova-1' were $1.40 \mathrm{~mm}$ (at width orientation), $0.85 \mathrm{~mm}$ (at length orientation) and $0.71 \mathrm{~mm}$ (at suture orientation).

The values of cracking force of 'Maraş-18' and 'Yalova-1' cultivars are shown in Tab. 3. As can be seen in Tab. 3 the values of cracking force of cv. 'Maraş-18' were found to be $227.6,184.8$, and $150.5 \mathrm{~N}$ at width, length and suture orientations, respectively. For cv. 'Yalova-1', the cracking force values obtained at width, suture, and length orientations were 184.9, 131.8, and $117.3 \mathrm{~N}$, respectively. As the same in deformation, the highest cracking force was observed at the width orientation for both cultivars. The value of highest cracking force was found at width orientation, followed by suture and length orientations by Koyuncu et al. (2004) for cv. 'Yalova-3', 'Altuntas' and Ozkan (2008) for cvs. 'Bilecik', 'Kaman' and 'Şebin'. The values of cracking forces obtained for cv. 'Maraş-18' was higher than cv. 'Yalova- 1 ' at all orientations. This could be due to the shell thickness of the cultivars: shell thickness of cv. 'Maraş-18' was higher than that of cv. 'Yalova-1'. Likewise, Koyuncu et al. (2004) reported that cracking force increased with increase in shell thickness of walnut. Also, as seen in Tab. 2, the cultivar with thick shell (cv. 'Maraş-18') showed a cracking force at width orientation higher than the cultivar with thin shell (cv. 'Yalova-1'). The results by Koyuncu et al. (2004) and Altuntas and Ozkan (2008) supported the present research.

The values of energy absorbed were found to be 185.5, 132.9 , and $64.8 \mathrm{~mJ}$ at width, length and suture orientations, respectively, for cv. 'Maraş-18' and 132.2, 54.6, and $53.3 \mathrm{~mJ}$ at width, suture and length orientations, respectively, for 'Yalova-1' (Tab. 3). For all loading orientations, the values of energy absorbed obtained for cv. 'Maraş-18' were higher than those of cv. 'Yalova-1' as the same in cracking force. Koyuncu et al. (2004) reported that energy absorbed values were positively correlated with the shell thickness along width and suture orientations.

The hardness values were found to be 208.1, 151.3, and $148.8 \mathrm{Nmm}^{-1}$ at suture, width and length orientations, respectively, for cv. 'Maraş-18' and 184.7, 140.5 and 133.6 $\mathrm{Nmm}^{-1}$ at suture, length and width orientations, respectively, for cv. 'Yalova-1' (Tab. 3). For all the loading orientations, the values of hardness of cv. 'Maraş-18' were higher than those of cv. 'Yalova-1'.

The grades of kernel extraction of 'Maraş-18' and 'Yalova- 1 ' cultivars were 99 and 97 for width orientation, 95 and 97 for length orientation and 95 and 96 for suture orientation, respectively (Tab. 3). As seen in Tab. 3, the grades of kernel extraction at width orientation resulted in the slightly higher than the other two orientations for cv. 'Maraş-18' while cv. 'Yalova-1' had the same grade of kernel extraction at all orientations.

\section{Conclusions}

There were statistical significant differences on all searched parameters between cultivars except width, mass, geometric mean diameter, and surface area for nuts and mass for kernels.

Both cultivars has relatively similar nut (12.44 and $12.70 \mathrm{~g}$ ) and kernel mass (7.38 and 7.40 g).

Fruit length and sphericity are the most distinct physical parameter between two cultivars.

The effect of loading orientation to kernel extraction quality was found insignificant.

\section{References}

Altuntas E, Yildiz M (2007). Effect of moisture content on some physical and mechanical properties of faba bean (Vicia faba L.) grains. J Food Eng 78:174-183.

Altuntas E, Ozkan Y (2008). Physical and mechanical properties of some walnut (Juglans regia L.) cultivars. Int J Food Eng 4:10-16.

Altuntas E, Gercekcioglu R, Kaya C (2010). Selected mechanical and geometric properties of different almond cultivars, Int J Food Properties 13:282-293.

Anonymous (2009). http://ciftci.ksu.edu.tr/cevhat/10_ceviz_ cesitleri.htm (accessed 16 February 2010).

Arslan S, Vursavus KK (2008). Physico-mechanical properties of almond nut and its kernel as a function of variety and moisture content. Philippine Agric Sci 91:171-179.

Aydin C (2002). Physical properties of hazelnuts. Biosyst Eng 82:297-303.

Balasubramanian D (2001). Physical properties of raw cashew nut. J Agric Eng Res 78:291-297.

Barut E (1997). Overview of walnut culture in Turkey. Acta Hort 442:435-438.

Baryeh EA (2001). Physical properties of Bambara groundnuts. J Food Eng 47:321-326.

Baytop T (1984). Therapy with Medicinal Plants in Turkey. Istanbul University Publication No 3255 (in Turkish).

Braga GC, Couto SM, Hara T, Almeida Neto JTP (1999). Mechanical behaviour of macadamia nut under compresssion loading. J Agric Eng Res 72:239-245.

Caglarirmak N (2003). Biochemical and physical properties of some walnut genotypes. Nahrung 47:28-32.

Ercisli S (2004). A short review of the fruit germplasm resources of Turkey. Gen Res Crop Evol 51:419-435.

FAO (2008). Food and Agricultural Organisation, Statistical Databases.

Galedar MN, Mohtesebi SS, Tabatabaeefar A, Jafari A, Fadaei H (2009). Mechanical behavior of pistachio nut and its kernel 
under compression loading. J Food Eng 95:499-504.

Kashaninejad M, Mortazavi A, Safekordi A, Tabil LG (2006). Some Physical Properties of Pistachio (Pistacia vera L.) Nuts and Its Kernel. J Food Eng 72:30-38.

Kocturk BO, Gurhan R (2007). Determination of mchanical properties of various walnut according to different moisture levels. J Agric Sci 13:62-68.

Koyuncu MA, Ekinci K, Savran E (2004). Cracking characteristics of walnut. Biosyst Eng 87:305-311.

Mohsenin NN (1986). Physical properties of plant and animal materials. Gordon and Breach Science Publisher, NY.

Oloso AO, Clarke B (1993). Some aspects of strength properties of cashew nuts. J Agric Eng Res 55:27-43.

Pliestic S, Dobricevic N, Filipovic D, Gospodaric Z (2008). Influence of moisture content on physical and mechanical properties of almond (Prunus dulcis cv. 'Fra Giulio Grande'). Transactions of the ASABE 51:653-659.
Sen SM, Tekintas FE (1992). A Study on the selection 231 Adilcevaz walnuts. Acta Hort 317:171-174.

Sirisomboon P, Kitchaiya P, Pholpho T, Mahuttanyavanitch W (2007). Physical and mechanical properties of Jatropha curcas L. fruits, nuts and kernels. J Food Eng 97:201-207.

Turgut N, Kara M, Erkmen Y, Guler IE (1998). Determination of static particle strength of granular fertilizer. Proc of $18^{\text {th }}$ Agricultural Mechanization National Congress, Tekirdag, Turkey, 785-794 p.

Visvanathan R, Palanisami PT, Gothandapani L, Sreenarayanan VV (1996). Physical properties of Neem Nut J Agric Eng Res 63:19-26. 